\title{
Towards personalized medicine...
}

Citation for published version (APA):

Brunner-La Rocca, H. P. (2014). Towards personalized medicine... Maastricht University. https://doi.org/10.26481/spe.20140627hb

Document status and date:

Published: 27/06/2014

DOI:

10.26481/spe.20140627hb

Document Version:

Publisher's PDF, also known as Version of record

\section{Please check the document version of this publication:}

- A submitted manuscript is the version of the article upon submission and before peer-review. There can be important differences between the submitted version and the official published version of record.

People interested in the research are advised to contact the author for the final version of the publication, or visit the DOI to the publisher's website.

- The final author version and the galley proof are versions of the publication after peer review.

- The final published version features the final layout of the paper including the volume, issue and page numbers.

Link to publication

\footnotetext{
General rights rights.

- You may freely distribute the URL identifying the publication in the public portal. please follow below link for the End User Agreement:

www.umlib.nl/taverne-license

Take down policy

If you believe that this document breaches copyright please contact us at:

repository@maastrichtuniversity.nl

providing details and we will investigate your claim.
}

Copyright and moral rights for the publications made accessible in the public portal are retained by the authors and/or other copyright owners and it is a condition of accessing publications that users recognise and abide by the legal requirements associated with these

- Users may download and print one copy of any publication from the public portal for the purpose of private study or research.

- You may not further distribute the material or use it for any profit-making activity or commercial gain

If the publication is distributed under the terms of Article $25 \mathrm{fa}$ of the Dutch Copyright Act, indicated by the "Taverne" license above, 


\section{Towards personalized medicine...}

\section{Rede}

Uitgesproken bi de aanvaarding van het ambt van bijzonder hoogleraar cardiologie in het bijzondere clinical heart failure aan de Faculty of Health, Medicine and Life Sciences van de Universiteit Maastricht

Maastricht, 27 juni 2014

Prof.dr. H.P. Brunner-La Rocca 
Mijnheer de rector magnificus

Decaan van de Faculteit Health, Medicine and Life Sciences

Gewaardeerde collega's

Lieve familie en vrienden

Geachte toehoorders

In principe zou ik mijn oratie graag in het Nederlands willen houden. Niet om te laten zien dat het toch redelijk zou lukken. Ook niet alleen om te laten zien dat ik het ook zo bedoel als ik zeg dat ik de mensen hier in Nederland niet alleen wil verstaan, maar ook begrijpen. Nee, ik zou het vooral willen omdat het Nederlands deel van mijn leven is geworden alsof ik dat ooit had gedacht. Maar zoals $u$ zult horen en het ongetwijfeld ook weet is mijn connectie met Zwitserland en de vrienden welke er wonen nog steeds sterk en ik stel het erg op prijs dat zo vele hier naartoe zijn gekomen. Daarom zal ik mijn oratie in het Engels houden.

It took me quite a while to now giving my inaugural lecture. To make the step working in another country away from home was in the end more difficult than I had thought. I had already once before the chance to train how it would be during our stay in Melbourne Australia, but making this step not just temporarily is different and quite an adventure. It is an experience to get settled in a new environment. You may think that there is hardly any difference between Switzerland and the Netherlands, both are small countries, both are sharing quite some common expertise and interests, both have similar things that are important to people. But, there is a difference. In the meantime, I have learned a lot. I have learned how to thoroughly discuss things. I learned that Limburg is well a province of the Netherlands, but that it is not Holland, even though they share some common interests. 5 years ago, I did not know the difference; now I do know. I also learned that if you get an invitation at $8 \mathrm{pm}$. you are expected to be fed. And I learned that "yes" does not always mean "yes" and "maybe" means "no", but also that even a clear "no" always leaves the option for a second chance.

I have also learned about important differences in the health care systems of the two countries. Having basically no specialists in private practice, a much stronger influence of health care insurers, a different financial system with DRG's/DOT's also in outpatient care require a different set-up of and approach to care. Comparing systems and learning from it provides interesting insights in health care that can be used to improve the care we are delivering to our patients.

But most importantly, I met many very friendly, helpful and enthusiastic people. I came along at a relatively young university; something I did not know from the past as both universities where I was working in Switzerland have been established for hundreds of years. There are some things specific to a new university, I think. There is the problem of being questioned, of being forced to prove the importance of the own existence. This might be seen as drawback, but to me, it is mainly an interesting challenge. A new university also means having a spirit of enthusiasm, achieving something new, reaching out for success. The 
same reasons were main drivers for me to do the step of going abroad. These attributes that we have here are crucial to tackle the challenges that are present for ongoing changes in health care, in education, but also in research.

Collaboration in this is very important. Something that took some effort for me to be achieved, but we are really making progress; within our heart failure cluster, within Cardiology, but also with other departments and even across schools; an aspect of my work that is really enjoyable. It is an honour to be part of a department where big discoveries in Cardiology have been made, but this obviously also asks for commitment. To a significant extent, this is visible and I am impressed about the expertise and knowledge that is available here in Maastricht. This is another important motivation for me to work here. Still, we must keep living up to this commitment and our expectations.

The controversy between being questioned and wanting to perform and to achieve more should not result to try to imitate what others are doing. In some ways, there are tendencies in this direction with e.g. too narrow foci on very specific topics. Instead, we should ask ourselves what are we really good in and what are we wanting to achieve in the future. Obviously, it is not my task to do this in a very broad term. Still, in Cardiology, I may dare to say that our strengths are not limited to one specific topic, but more the impressive variety of expertise present, from bench to bedside. This became also obvious during the external review of CARIM that had taken place this month. Even more importantly, the different groups are exchanging ideas and are collaborating. There are certainly fields, where we could, no must further improve. We also must be more visible from the outside herein. But, we have a good basis to be very successful in this regard. In many ways, this is the topic of my speech today.

The topic of my speech is, as you know, "towards personalized medicine...". And to me, this obviously means in heart failure. But how can I say that we should not be focussing on one specific topic if I am saying to do the same? This is obviously the challenge in this. Being broadly focused... a "contradictio in adiecto", a contradiction in terms? I do not think so. To me, personalized medicine is asking for more than what we have been doing in Cardiology so far. And heart failure is the perfect playground for this; complex, being the (end-)result of almost all cardiac diseases, dealing with patients that usually do not only have heart failure, but many other diseases, numerous adaptive mechanisms being of importance, despite advantages in the recent decades still much to be achieved, both with respect to outcome and quality of life of patients, and in particular, a one-fits all approach with very little attempts to go in a different direction.

\section{Heart failure - a common and deadly disease}

Heart failure is mainly, but not exclusively a disease of the elderly. The prevalence increases with age from far below $1 \%$ at the age below 50 years to $10 \%$ or more in people aged above 75 years. Thus, at least ever $10^{\text {th }}$ person at this age has heart failure. It is estimated that app. 15 million patients suffer from heart failure in Europe and there are more than one million new cases each year worldwide. Heart failure is the most common reason for hospitalization in patients aged more than 65 years. As a consequence, it is also a 
very costly disease, accounting for app. $2 \%$ of the total health care budget in developed countries.

Usually, heart failure is a progressive disease(1). There are some exceptions such as some patients with myocarditis or as a result of exposure to toxic substances such as alcohol or chemotherapy. In the majority, however, patients do not completely recover from it. After initial presentation with symptoms such as shortness of breath, the patients usually can be stabilized with current treatment. Still, after a period of little symptoms, which may vary significantly from months to more than a decade in individual patients, cardiac function progressively deteriorates with episodes of hospital admission. Functioning of the patients gradually deteriorates until the terminal stage, finally leading to death. Some patients may also die suddenly from fatal arrhythmias at earlier stages. Treatment of heart failure is obviously to prevent both as far as possible.

And, we have been quite successful in this during the last 25 years. In the late 80 's, more than half of the patients with advanced heart failure died within one year! Undoubtedly, one of the most deadly diseases then. Fortunately, different types of medication and also device therapy such as implantable defibrillators and biventricular pacemakers have dramatically improved outcome in heart failure patients. Based on the large studies that have investigated these therapies, one could expect a yearly mortality rate of $10 \%$ or even less. However in clinical reality, figures are less optimistic than this. In our own hospital, app. $10 \%$ of the patients that are admitted with the diagnosis of heart failure die during the hospital stay and app. 13\% are readmitted to hospital with 30 days (Source: Global Comparators provided by dr. Foster, UK)! These data have been collected in an international collaboration with 44 institutions in 8 different countries called Global Comparators. This collaboration is to improve in-hospital care by comparing data and exchanging information on organization of care. The big need of such initiatives is highlighted by results such as ours that are similarly being seen in other centres. Also during post-discharge care, there is still much to be won as shown by the results of the TIME-CHF study, which included a typical heart failure population with an average age of 76 years. Mortality during the first year was $20 \%$ and $50 \%$ died within 4 years after discharge from hospital $(2,3)$.

The question obviously arises why are these figures much worse than what might be expected from the large clinical trials? There are several answers to this, but frankly, much is unknown about it. What certainly plays a role is the presence of multiple diseases other than heart failure in the majority of patients, called co-morbidities. As recently described in the US patients hospitalised with heart failure, hospitalisation primarily due to heart failure tend to decrease from $30 \%$ in 2001 to $26 \%$ in 2009 of all hospitalisations related to heart failure(4). In contrast, heart failure hospitalisations accompanied with other problems have been increasing. Thus, renal failure was a major reason for admission in $11 \%$ in 2001, but increased to $40 \%$ in 2009 , and mental illnesses increased from $25 \%$ to $38 \%$. Other diseases increased less dramatically, but these figures illustrate the increasing complexity of patients with heart failure. In such patients, in-hospital mortality is more than twice the mortality of those with heart failure only. 
Another potential reason for the less favourable outcome is insufficient adherence of physicians to guidelines. In a survey, cardiologists, internists and geriatricians were asked about the way how they are treating patients with heart failure(5). Among other, reasons for not giving $\beta$-blockers, an important cornerstone in heart failure therapy, were asked. Many reasons were given, but most of them are no contra-indications following the current guidelines. Cardiologist did only slightly better than the other two groups. E.g. $60 \%$ of cardiologists and $70 \%$ of internists and geriatricians named COPD as a contra-indication although various studies have shown equal benefit from $\beta$-blocker treatment in these patients. Recently in the US, the impact of not following the guidelines was calculated theoretically. The authors concluded that as many as 68.000 lives could be saved each year in the US just by treating heart failure adequately(6)!

\section{Care processes in heart failure}

Why are not we doing any better than this? The complexity of treating patients with heart failure is a key issue. Many caregivers as well as the patients are involved in the treatment of heart failure. This not only includes the cardiologist and the general practitioner (GP), but depending on the individual need of a patient many other specialists, heart failure nurses, pharmacologist, dietist, physiotherapist and many other. Many questions in this complex network are not really addressed such as the most adequate caregiver at a certain time-point, most adequate ways of communication and documentation, adequacy of treatment and so forth. Many problems are to be addressed. They may include coordination of care, communication pathways, optimal way to approach multiple chronic disorders, benchmarking and adequacy of individual guidelines for different diseases, which may be contradictory in some aspects. Moreover, improvement of efficacy and efficiency to reduce costs at better quality has not been addressed. And very importantly, patients must be adequately integrated in the care process. Obviously, this long list is far from being complete. In addition, little is known about the importance of each of these hurdles.

INTERACT-in-HF tries to answer many of these questions by investigating how the careprocess in heart failure is organized in order to define important bottlenecks. In this study, we are using a patient-centred, mixed-method research approach. Thus, we have interviewed 33 patients from our outpatient clinic to determine how care was carried out in each patient. Aspects of this include the diagnostic steps being made, the therapy given, caregivers involved, hurdles the patients experienced, etc. In addition, their cardiologists, heart failure nurses and GP's were interviewed. Presently, we are interviewing 15 heart failure patients only seen in primary care and their GP's to investigate important differences between primary and secondary care. Moreover, the approach is being applied in two regions in Germany and Belgium to address differences between different health care systems. The data are being verified by collecting data about the care process of another 150 randomly selected heart failure patients from the patients' records in each region.

The experience of this study already helped to better define the needs for collaborating with GP's in the region. The "11/2 lijnzorg" project focuses in heart failure on 
best treatment in the whole care process, particularly the long-term treatment to implement "best practice" in the region. Obviously, the aim is also to define this more broadly and independently of the health care system to develop integrated care programs. An important basis for this will be the integration with ICT supported care. There is considerable experience with ICT supported care here in Maastricht $(7,8)$ and we are further developing and improving telemedicine in collaboration with an industrial partner. The aim is not only to provide easier access to care and improvement in the aspects mentioned above, but to also substitute care to some extent, resulting in reduction in cost and improvement in care likewise. Obviously, the ICT basis will additionally be used to implement results of the other initiatives as highlighted below as well as knowledge from basic research programs of CARIM.

\section{Best care known in all HF patients? Steps towards personalized medicine}

Guidelines give recommendations regarding all patients with heart failure. However, these recommendations are evidence based only in those aged 75 years or less with reduced left-ventricular ejection fraction (LVEF). In those with normal LVEF, so-called heart failure with preserved ejection fraction (HFpEF), no treatment is known to improve outcome(9). Only a limited amount of trials have been performed so far, of which all failed to show significant benefits. One important reason for this failure is the fact that HFpEF is, in our opinion, not one uniform disease with uniform pathophysiology. Therefore, we suggest a completely different approach to HFpEF by establishing a new outpatient clinic for these patients with an important focus on extensive diagnostics. This will help to much better address the underlying problems in individual patients which then can be targeted with specific therapies. We are establishing an electronic database and a biobank in these patients to further develop treatment algorithms for best practice in these patients. A very strong translational part is playing an important role in this, as the cohort will provide samples for basic research questions, will help to define new questions that can be address in basic research and will give the opportunity of bringing findings from basic research to these patients in urgent need for better therapy.

Apart from this, the question arises to what extent personalized medicine is already implemented in the management of heart failure. The answer is to a very limited extent. Obviously, we are treating patients based on symptoms and we are treating underlying problems such as myocardial infarction or valvular diseases. We are treating complications of heart failure and we are adjusting medication based on tolerability. But, we would like to tailor therapy much more targeted to the individual need. This is to a large extent still fiction. Markers of prognosis might be helpful in this, but in clinical reality this is presently limited to the indication for cardiac transplantation. Some studies have used NT-proBNP to better guide therapy in heart failure patients, among those TIME-CHF in which I was substantially involved, is still the largest $(10,11)$. These studies suggested that NT-proBNP / BNP may be used to optimize therapy(12), but this is obviously a non-specific approach. Other biomarkers as well as genetic profiles are not yet studied to guide therapy. Therefore, we are using standard drug and device regimen according to the guidelines quite unselectively in treating our heart failure patients. 
There are, however, potential shortcomings in this. Thus, it is very likely that the premises are not the same for all patients and that effects of treatment are quite different between patients. As a consequence, the chance of a beneficial effect of a particular treatment is not really predicable. The questions as to whether there are better options than to give everything to everybody can probably be answered by saying yes, but this has not yet been studied. As suggested by studies such as TIME-CHF, biomarkers might play an important role in this regard. Biomarkers are markers of biological processes. Broadly spoken, this may include measures such as heart rate or blood pressure. Usually, the term biomarker refers, however, more specifically to markers circulating in the peripheral blood of which NT-proBNP used in TIME-CHF is a prominent example. There are currently many initiatives on biomarkers not just in heart failure, using 100s or even 1.000s of biomarkers. Given the complexity and the lack of understanding of many details on these biomarkers, I am convinced that these initiatives are likely to fail, at least in the short and mid-term.

Therefore, we are using a different approach. In TIME-CHF, we measured 20 additional biomarkers at all visits when patients were seen during the study. Currently, we are investigating how the interaction between these biomarkers and the medication during the time-course of the study predicts the probability that patients are doing fine. In collaboration with the Department of Knowledge Engineering of Maastricht University and an industrial partner, we are looking for individual biomarkers that predict the effects of distinct classes of drugs on patient outcome. The figure depicts an example, showing a better response to high doses of $\beta$-blockers if the biomarker is low, but to low doses of $\beta$ blockers if the biomarker is high. This would be a completely new concept in the treatment of heart failure that could result in a paradigm shift. If this new concept can be confirmed it would allow targeting specific treatment in individual patients. The results of TIME-CHF are currently tested in 4 other international cohorts of heart failure patients, including in total $>5.000$ patients. Both clinical data and blood samples to measure biomarkers are provided from these groups to us that we can further work out this concept. Initial results are very promising.

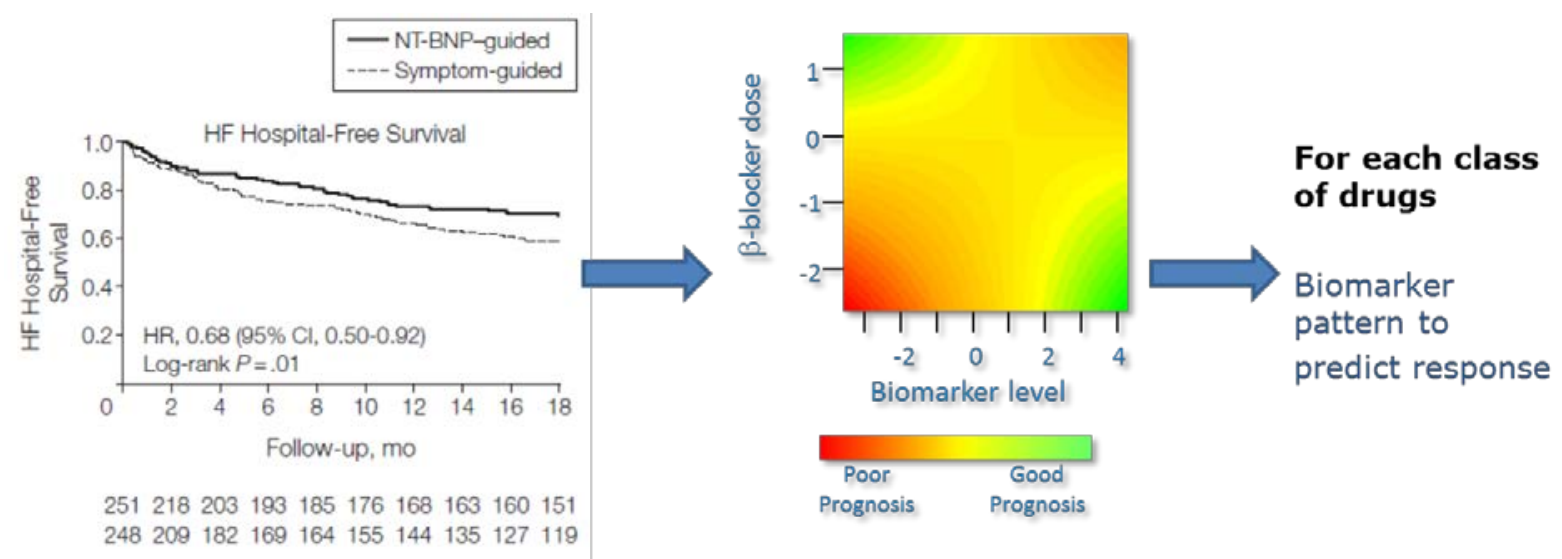

Figure: from TIME-CHF(10) (left) to truly personalized heart failure medication. Middle figure shows example from interaction between biomarker and medication to predict treatment response. 
After validation of these results, prospective studies will be conducted. We are expecting to have the validation competed early next year. This would be a truly personalized approach for treatment of heart failure, beyond current practice. Based on individual patterns of clinical findings and biomarkers optimal therapy may be defined with high dose of drugs only where needed, but low doses or even omitting of some drugs where required. This will result in least side effects, best outcome and being most cost-efficacious. In a latter step, genetic information may be included.

\section{Co-Morbidities and patients' wish}

In order to cover the "full picture", consideration of the co-morbidities is additionally needed. It is known that each co-morbidity independently impact outcome in a negative way(13). Thus, the risk of more than one additional disease is additive, resulting in a huge increase in risk to die in such patients as compared to those only having heart failure. In addition to the increased risk, making optimal medical therapy becomes close to impossible as all these diseases require different treatment. Investigating heart failure in isolation, therefore, results in a major shortcoming for clinical practice. We are, therefore, investigating the interaction between heart failure and other diseases. One prominent example of this is the investigation of cognitive impairment in heart failure(14). Together with 3 other centres in the Netherlands, we are conducting comprehensive testing including imaging using MRI of heart, brain and cerebral vessels, cognitive assessment as well as biomarkers. Thus, the interaction between heart, blood flow to the brain and the brain is investigated in three populations: i.e. heart failure, carotid stenosis, and vascular cognitive impairment. Using such an integrative approach is also applied to other co-morbidities, particularly where needed most, which is in HFpEF patients.

Finally, it is all about the patients. We tend to forget that patients may have other priorities than we think they have. Asking them about their preferences and their quality of life is therefore crucial. We did so and what we found was rather surprising to us. Thus, $3 / 4$ of the patients would not have been willing to give one single day of their remaining lifespan for a better quality of life; despite being elderly and having significant symptoms related to heart failure(15). This is a finding that is completely different to what we expected. And, it was not possible to predict the preferences of individual patients. This goes along nicely with the investigation of the care processes. Asking what it is all about is crucial; knowing is everything, guessing is nothing. Unfortunately, guessing is what we are often doing in the care of heart failure, but also when planning research. Our projects can be seen as a serious try to overcome this shortcoming.

\section{Conclusions and outlook}

The overall aims of the clinical heart failure group is, therefore, working towards personalized medicine in heart failure using a holistic approach. This does not only include heart failure itself, but also co-morbidities and patients' preferences. It aims to setting up personalized therapy applied to the individual needs of heart failure patients covering the full spectrum. Moreover, it aims to much better facilitate heart failure care by knowing the important processes, identifying and targeting bottlenecks, and creating a basis that is 
widely applicable. ICT supported care will play an important role in this because comprehensive information over patients and their individual needs are crucial in this. Further development in collaboration with other academic and industrial partners is key and will include applications for EU grants. I am convinced that only a broad approach in clinical heart failure care as well as research will help to overcome current obstacles.

Very important in this is the close collaboration with basic research because both sides are limited if there is no exchange. At first sight and as addressed here, there is much to be done to even implement current knowledge in clinical practice. Only focusing on this would, however, mean stagnation not only on longer term. Basic research is dependent on knowing the clinically important questions and needs a partner to bring their findings to patients, whereas clinical research is dependent on innovation and understanding of mechanisms, just to name a few important aspects of such interaction. There is, however, still a gap between the understanding of basic mechanisms and clinical practice. This gap is significantly hindering progress. Within the heart failure cluster, we are moving ahead with reducing this gap. Still, there are also threats. Given the constraints to reduce costs in health care, the mistake is often being made to prioritize research and education much lower than clinical care. As clinical research can somewhat more easily be integrated in clinical care and industrial money is more easily available for clinical research, it is mainly basic research that is suffering from this. On short term, this saves money. On the longer term, this questions the justification of existence of a university. There are other ways to reduce costs and to be more efficient. Thus, effort can be placed on optimizing processes and workflows. This has recently been started in our institution, but more needs to be done. Another example is the fact that the hospital and the university are still two different legal bodies; something I just do not understand and I have not heard any convincing reasons why this has not been changed. Maastricht - the university with all the schools and the hospital - is aiming high, but has to be aware what the consequences are to live up with this. The new developing cardiovascular centre with the very ambitious aims fits excellently in this. To be part of these new developments is very exciting and an important reason for me to work here. Thoroughly believing in it by all involved and putting the ambitions into practice even more than presently being done are crucial to reach these aims. I am proud to be part of it and to be able to contribute to the success of it.

\section{Acknowledgement}

At the end of my speech, I would like to express some words of acknowledgement. All what I did and what I have achieved would have been impossible without the support of so many, a lot of them sitting here in the audience. I would like to thank you all for being here. I would like to express my deepest gratefulness to all the support. At a moment like this one, one thinks back to all what happened and to all the people that played a role in this. I ended up with an unbelievably long list of people. It is obviously impossible to name all and that does in no ways mean that I am not grateful to them. Still, I would like to express special thanks to some, but please forgive me if I may forget somebody or do not mention personally. 
First of all, I would like to thank and remember my parents for all what they made possible for me. Unfortunately, they passed away years ago and can no longer be amongst us. Still, I know that this would be a very special moment for them and that they would have supported me in my decision to come here to Maastricht.

Obviously, I am celebrating a professional achievement. Still, without my friends, past and present, I would not be here. I really want to tell you all how important you are to me. I thank you all for what you are doing for me. I would like to thank Mark "Beni" Bernheim particularly for being my best friend for already more than 35 years. Countless memories, we are sharing together.

Many colleagues from Switzerland but also other countries have significantly contributed to my development and achievements. It is not possible to be successful without a mentor. Wolfgang Kiowski was my mentor whom I owe much. Unfortunately, he passed away much too early and I am missing his advice. Many colleagues went along with me during my carrier. When I was a young assistant in training, Daniel Schlossberg, but also later as staff. All those who did research with me were obviously particularly important. When I started with clinical research in Zurich, with special thanks to Daniel Weilenmann, later in Australia, and then back in Zurich; Christine Attenhofer-Jost, Hans Rickli, Erwin Oechslin, Christoph Scharf. Later during my work as cardiologist in Basel, I had the opportunity to participate in high altitude research, which was just a little bit more than pure research. Alain Bernheim, Beat Kaufmann, Marco Maggiorini and Susi Kriemler played important roles in this. A very special thank goes to all the TIME-CHF investigators and co-investigators. More than 100 people contributed to the success of this study and it would have been impossible to complete it so successfully without them. Some of those who contributed I would like to mention personally. On the one hand, the research assistants working in Basel were very important for the success of the study. I also thank specially Micha Maeder for his contribution. And, the study would have been impossible without Ruth Schindler. She was basically the heart of TIME-CHF, but contributed also to many things.

Here in Maastricht, I met many nice and interesting people, which makes it enjoyable, mostly, to work and live here. I would like to express my thanks to those who made it possible for me to come here: Mat Daemen, Guy Peeters, Michael Jacobs and particularly Harry Crijns; Harry who is giving me a lot of opportunities. I thank the Executive Boards of CARIM and of the hospital and the dean of the Faculty of Health, Medicine and Life Sciences of the University of Maastricht for the trust in me. Particular thanks go to the heart failure team of our department. Without them it would be impossible to achieve anything; Christian Knackstedt, Vanessa van Empel, Nicole Lencer and Simon Schalla. I would like to thank Stephane Heymans for the collaboration not just locally, but particularly in international studies and the link between basic and clinical research; Leon de Windt and all the colleagues at CARIM who are collaborating with me. My PhD students who are doing an excellent job with their theses, but who also help me a lot in many other ways, particularly Sema Bektas and Désirée Rutten and very special thanks to Sandra Sanders-van Wijk who helped me a lot with so many things. Thanks to the heart failure nurses, with special thanks to Josiane Boyne for being a supportive sparing-partner. Many thanks to all colleagues of the 
department of Cardiology for a very pleasant collaboration and support, but also to all the residents and assistants of our department who I really like to work with. Many thanks to the nurses, technicians and the whole staff of Cardiology and special thanks to our office, particularly to Lianne Braam who is giving me enormous support. I would also like to thank all colleagues from the other departments, particularly cardio-thoracic surgery, and the colleagues from other schools with whom we are doing research namely CAPHRI where collaboration really starts picking up such as with Jan Hamers and Jos Schols. I would also like to thank the colleagues from the Department of Knowledge Engineering, particularly Ralf Peeters and the PhD student we are sharing Nasser Davarzani for doing all the calculations I am dependent on. Finally, I would also like to thank many people from the industry who supported our research in all these years. In this regard, I would like to particularly thank Christian Zaugg.

And I would like to thank one person very explicitly, my lovely wife Gabriela. I am most grateful to you for all what you have been doing for me for so many years and what you mean to me. I know that I am asking a lot, with respect to our current situation of living in two different countries, but also for sharing my sometimes strange ideas and believing in me in severe weather conditions; the latter being meant not just literally.

Ik heb gezegd. 


\section{Reference List}

1. Goodlin SJ. Palliative care in congestive heart failure. J Am Coll Cardiol 2009;54(5):386-396.

2. Maeder MT, Rickenbacher $P$, Rickli $H$, Abbuhl $H$, Gutmann $M$, Erne P, Vuilliomenet $A$, Peter $M$, Pfisterer M, Brunner-La Rocca HP. N-terminal pro brain natriuretic peptide-guided management in patients with heart failure and preserved ejection fraction: findings from the Trial of Intensified versus standard medical therapy in elderly patients with congestive heart failure (TIME-CHF). Eur J Heart Fail 2013;15(10):1148-1156.

3. Sanders-van Wijk S, Maeder MT, Nietlispach F, Rickli H, Estlinbaum W, Erne P, Rickenbacher P, Peter M, Pfisterer MP, Brunner-La Rocca HP. Long-Term Results of Intensified, N-TerminalPro-B-Type Natriuretic Peptide-Guided Versus Symptom-Guided Treatment in Elderly Patients With Heart Failure: Five-Year Follow-Up From TIME-CHF. Circ Heart Fail 2014;7(1):131-139.

4. Blecker S, Paul M, Taksler G, Ogedegbe G, Katz S. Heart failure-associated hospitalizations in the United States. J Am Coll Cardiol 2013;61(12):1259-1267.

5. Remme WJ, McMurray JJ, Hobbs FD, Cohen-Solal A, Lopez-Sendon J, Boccanelli A, Zannad F, Rauch B, Keukelaar K, Macarie C, Ruzyllo W, Cline C. Awareness and perception of heart failure among European cardiologists, internists, geriatricians, and primary care physicians. Eur Heart J 2008;29(14):1739-1752.

6. Fonarow GC, Yancy CW, Hernandez AF, Peterson ED, Spertus JA, Heidenreich PA. Potential impact of optimal implementation of evidence-based heart failure therapies on mortality. Am Heart J 2011;161(6):1024-1030.

7. Boyne JJ, Vrijhoef HJ, Crijns HJ, De WG, Kragten J, Gorgels AP. Tailored telemonitoring in patients with heart failure: results of a multicentre randomized controlled trial. Eur J Heart Fail 2012;14(7):791-801.

8. Hendriks JM, de WR, Crijns HJ, Vrijhoef HJ, Prins MH, Pisters R, Pison LA, Blaauw Y, Tieleman RG. Nurse-led care vs. usual care for patients with atrial fibrillation: results of a randomized trial of integrated chronic care vs. routine clinical care in ambulatory patients with atrial fibrillation. Eur Heart J 2012;33(21):2692-2699.

9. Leibundgut G, Pfisterer M, Brunner-La Rocca HP. Drug treatment of chronic heart failure in the elderly. Drugs Aging 2007;24(12):991-1006.

10. Pfisterer $M$, Buser $P$, Rickli $H$, Gutmann $M$, Erne $P$, Rickenbacher $P$, Vuillomenet $A$, Jeker $U$, Dubach P, Beer H, Yoon SI, Suter T, Osterhues HH, Schieber MM, Hilti P, Schindler R, BrunnerLa Rocca HP. BNP-guided vs symptom-guided heart failure therapy: the Trial of Intensified vs Standard Medical Therapy in Elderly Patients With Congestive Heart Failure (TIME-CHF) randomized trial. JAMA 2009;301(4):383-392.

11. Brunner-La Rocca HP, Buser PT, Schindler R, Bernheim A, Rickenbacher P, Pfisterer M. Management of elderly patients with congestive heart failure--design of the Trial of Intensified versus standard Medical therapy in Elderly patients with Congestive Heart Failure (TIME-CHF). Am Heart J 2006;151(5):949-955.

12. Troughton RW, Frampton CM, Brunner-La Rocca HP, Pfisterer M, Eurlings LW, Erntell H, Persson P, O'Connor CM, MoertI D, Karlstrom P, Dahlstrom U, Gaggin HK, Januzzi JL, Berger R, 
Richards AM, Pinto YM, Nicholls MG. Effect of B-type natriuretic peptide guided treatment of chronic heart failure on total mortality and hospitalisation: an individual patient meta-analysis. Eur Heart J 2014;35(23):1559-1567.

13. Jong $P$, Vowinckel E, Liu PP, Gong Y, Tu JV. Prognosis and determinants of survival in patients newly hospitalized for heart failure: a population-based study. Arch Intern Med 2002;162(15):1689-1694.

14. Huijts M, van Oostenbrugge RJ, Duits A, Burkard T, Muzzarelli S, Maeder MT, Schindler R, Pfisterer ME, Brunner-La Rocca HP. Cognitive impairment in heart failure: results from the Trial of Intensified versus standard Medical therapy in Elderly patients with Congestive Heart Failure (TIME-CHF) randomized trial. Eur J Heart Fail 2013;15(6):699-707.

15. Brunner-La Rocca HP, Rickenbacher P, Muzzarelli S, Schindler R, Maeder MT, Jeker U, Kiowski W, Leventhal ME, Pfister O, Osswald S, Pfisterer ME, Rickli H. End-of-life preferences of elderly patients with chronic heart failure. Eur Heart J 2012;33(6):752-759. 